\title{
Nicotine enhances murine airway contractile responses to kinin receptor agonists via activation of JNK- and PDE4-related intracellular pathways
}

Yuan Xu, Yaping Zhang ${ }^{*}$, Lars-Olaf Cardell

\begin{abstract}
Background: Nicotine plays an important role in cigarette-smoke-associated airway disease. The present study was designed to examine if nicotine could induce airway hyperresponsiveness through kinin receptors, and if so, explore the underlying mechanisms involved.

Methods: Murine tracheal segments were cultured for 1, 2 or 4 days in serum-free DMEM medium in presence of nicotine (1 and $10 \mu \mathrm{M})$ or vehicle (DMSO). Contractile responses induced by kinin $\mathrm{B}_{1}$ receptor agonist, des-Arg ${ }^{9}$ bradykinin, and $B_{2}$ receptor agonist, bradykinin, were monitored with myographs. The $B_{1}$ and $B_{2}$ receptor mRNA expressions were semi-quantified using real-time PCR and their corresponding protein expressions assessed with confocal-microscopy-based immunohistochemistry. Various pharmacological inhibitors were used for studying intracellular signaling pathways.
\end{abstract}

Results: Four days of organ culture with nicotine concentration-dependently increased kinin $B_{1}$ and $B_{2}$ receptormediated airway contractions, without altering the kinin receptor-mediated relaxations. No such increase was seen at day 1 or day 2. The airway contractile responses to $5-\mathrm{HT}$, acetylcholine and endothelin receptor agonists remained unaffected by nicotine. Two different neuronal nicotinic receptor antagonists MG624 and hexamethonium blocked the nicotine-induced effects. The enhanced contractile responses were accompanied by increased mRNA and protein expression for both kinin receptors, suggesting the involvement of transcriptional mechanisms. Confocal-microscopy-based immunohistochemistry showed that 4 days of nicotine treatment induced activation (phosphorylation) of c-Jun N-terminal kinase (JNK), but not extracellular signal-regulated kinase 1 and 2 (ERK1/2) and p38. Inhibition of JNK with its specific inhibitor SP600125 abolished the nicotine-induced effects on kinin receptor-mediated contractions and reverted the enhanced receptor mRNA expression. Administration of phosphodiesterase inhibitors (YM976 and theophylline), glucocorticoid (dexamethasone) or adenylcyclase activator (forskolin) suppressed the nicotine-enhanced airway contractile response to des-Arg'-bradykinin and bradykinin.

Conclusions: Nicotine induces airway hyperresponsiveness via transcriptional up-regulation of airway kinin $B_{1}$ and $B_{2}$ receptors, an effect mediated via neuronal nicotinic receptors. The underlying molecular mechanisms involve activation of JNK- and PDE4-mediated intracellular inflammatory signal pathways. Our results might be relevant to active and passive smokers suffering from airway hyperresponsiveness, and suggest new therapeutic targets for the treatment of smoke-associated airway disease.

\footnotetext{
* Correspondence: Yaping.Zhang@ki.se

Division of Ear, Nose and Throat Diseases, CLINTEC, Karolinska Institutet,

Karolinska University Hospital, Huddinge, Sweden
} 


\section{Introduction}

Airway hyperreactivity is a major feature of asthma and a consequence of airway inflammation. It is well-known that both active $[1,2]$ and passive cigarette smoke exposure $[3,4]$ can cause airway hyperresponsiveness (AHR). Maternal cigarette smoking increases the risk for wheezing in early life and the development of childhood asthma $[5,6]$. Second-hand smoke exposure in asthmatics is associated with poor asthma control, greater asthma severity and greater risk of asthma-related hospital admission [7]. In vivo studies in guinea pigs have demonstrated that chronic exposure to tobacco smoke selectively increases airway reactivity to bradykinin and capsaicin, without altering responses to methacholine or histamine [8]. This suggests an important role for bradykinin in tobacco smoke-induced AHR.

Tobacco smoke is a composite of irritant molecules, including nicotine, acetaldehyde, formaldehyde, nitrogen oxides, and heavy metals, and long-term exposure results in chronic airway inflammation, AHR and in some individuals, chronic obstructive pulmonary disease (COPD). Nicotine is one of the more important components of cigarette smoke. It is also widely marketed as an aid to smoke cessation in forms of nicotine-replacement products. Once inhaled, nicotine is quickly taken up by the bloodstream and distributed throughout the body, to act primarily on nicotinic acetylcholine receptors. In humans, functional nicotinic receptors, of both the muscle and neuronal subtypes, are present on fibroblasts and in bronchial epithelial cells. They have the ability to activate protein kinase $C$ as well as members of the mitogen-activated protein kinases (MAPKs) including extracellular signal-regulated kinase 1 and 2 (ERK1/2) and p38 [9]. Many of the detrimental health effects of cigarette-smoke are believed to be due to nicotine's ability to affect the immune system. Stimulation of the nicotinic receptor produces complex reactions including both inflammatory [10] and anti-inflammatory effects [11], including modulation of allergic responses [12]. There is also evidence suggesting that nicotine can directly interfere with the phosphorylation of intracellular inflammatory signal molecules such as c-Jun N-terminal kinase (JNK) and ERK1/2, without involvement of the nicotinic receptors [13]. However, the knowledge about the intracellular mechanisms behind nicotine's effects is still limited.

Inhibition of phosphodiesterases (PDEs) results in the elevation of cyclic AMP (cAMP) and cyclic GMP (cGMP) which lead to a variety of cellular effects including airway smooth muscle relaxation and inhibition of cellular inflammation [14]. The archetypal non-selective PDE inhibitor theophylline shows anti-inflammatory properties and has been used clinically for more than 70 years. However, its narrow therapeutic window and extensive interactions with other drugs limits its clinical use. PDE4 is specific for the break-down of intracellular cAMP and PDE4 inhibitors have been intensely investigated for the treatment of asthma and COPD. The PDE4 subtype PDE4D5 has been recently shown to be the key physiological regulator of beta-adrenergic receptor-induced cAMP turnover within human airway smooth muscle [15]. It is well-known that cells respond to stimuli through a "network" of different signaling pathways. Interestingly, the cAMP pathway can interact with the MAPK cascade. CAMP negatively regulates MAPK p38 activation, and thereby contributing to tumor necrosis factor (TNF)- $\alpha$-induced apoptosis in certain cell types [16]. Activation of ERK5 and the subsequent transcription of c-JUN, but not ERK1/2, can be blocked by cAMP through cAMP-dependent protein kinase (PKA) [17].

Airway G-protein coupled receptors (GPCR), such as kinin, 5-hydroxytryptamine (5-HT), endothelin and muscarinic acetylcholine receptors, not only mediate airway smooth muscle contraction, but also airway inflammation and remodelling [18]. We have previously, by using an in vitro model of chronic airway inflammation, demonstrated that cytokines can induce transcriptional up-regulation of kinin $B_{1}$ and $B_{2}$ receptors and subsequently increase kinin receptor-mediated contractions [19]. Our receptor characterization studies using specific pharmacological antagonists have demonstrated that the $B_{1}$ receptor is selectively activated by des-Arg ${ }^{9}$-bradykinin, whereas the $B_{2}$ receptor is activated by bradykinin [20]. The $B_{2}$ receptor is constitutively expressed in airways, while the $B_{1}$ receptor is inducible following tissue injury and inflammation [21]. Stimulation of the kinin receptors in airways causes both bronchoconstriction and epithelium-dependent relaxation, as well as mucus secretion, edema and cough. The relaxation is mediated via activation of cyclooxygenase $(\mathrm{COX})$ and release of the bronchodilator prostaglandin $\mathrm{E}_{2}\left(\mathrm{PGE}_{2}\right)$ [21]. The mechanism behind AHR to kinins appears to involve activation of intracellular MAPKs and the down-stream transcription factor nuclear factor-kappaB (NF- $\kappa \mathrm{B})$ [20,22].

One of the hypotheses of the present study is that long-term exposure to nicotine can induce activation of airway MAPK-mediated inflammatory signal pathways and subsequently cause AHR via up-regulation of kinin receptors. This idea is based on previous data revealing activation of MAPK-mediated NF- $\kappa$ B inflammatory signal pathways in AHR along with an up-regulation of kinin receptors [20,22,23]. This is further corroborated by in vivo studies showing selective up-regulation of kinin receptors after exposure to cigarette smoke [8] 
and by in vitro results presenting activation of MAPK in human bronchial cells following stimulation of nicotinic receptors [9].

Reports of a role for PDE4 inhibitors in asthma and COPD treatment [14] together with the known interactions between the MAPK and cAMP pathways $[16,17]$ lead to our interest for possible nicotine-induced changes in PDE4 and cAMP pathway. Thus, the present study was designed to investigate if long-term exposure to nicotine could induce AHR to bradykinin and des$\mathrm{Arg}^{9}$-bradykinin through the selective up-regulation of kinin receptors and to explore the underlying intracellular inflammatory signal transduction mechanisms involved, with focus on both MAPK and PDE4.

\section{Materials and methods Tissue preparation}

Male BALB/c J mice (9-10 weeks old) were sacrificed by cervical dislocation. The whole trachea was rapidly removed and placed into cold Dulbecco's modified Eagle's medium (DMEM; $4500 \mathrm{mg} \mathrm{L}^{-1} \mathrm{D}$-glucose, 110 $\mathrm{mg} \mathrm{L}^{-1}$ sodium pyruvate, $584 \mathrm{mg} \mathrm{L}^{-1} \mathrm{~L}$-glutamine). For in vitro pharmacology and immunohistochemistry studies, the trachea was cut into ring segments, each containing three cartilage rings, while the whole trachea was kept intact for real-time PCR studies. The experimental protocol was approved by the local Ethics Committee.

\section{Organ culture}

The tracheal rings, alternatively the whole trachea, were placed individually in wells of a 96- or 24-well plate (Ultra-low attachment; Sigma, St. Louis, MO, U.S.A.) with $300 \mu \mathrm{L}$ or $1 \mathrm{~mL}$ serum-free DMEM culture medium supplemented with penicillin $\left(100 \mathrm{U} \mathrm{mL}^{-1}\right)$ and streptomycin $\left(100 \mu \mathrm{g} \mathrm{mL}^{-1}\right)$. All tissue were incubated at $37^{\circ} \mathrm{C}$ in humidified $5 \% \mathrm{CO}_{2}$ in air with either nicotine (1 or $10 \mu \mathrm{M}$ ), vehicle (dimethyl sulfoxide, DMSO, $0.1 \%$ ) or nicotine $(10 \mu \mathrm{M})$ plus various inhibitors for 1,2 or 4 days. The segments were transferred to new wells containing fresh medium with supplements of nicotine, vehicle or inhibitors every day.

\section{In-vitro pharmacology}

The cultured tracheal ring was immersed in temperature-controlled $\left(37^{\circ} \mathrm{C}\right)$ myograph bath (Organ Bath Model 700 MO, J.P. Trading, Aarhus, Denmark) containing $5 \mathrm{ml}$ Krebs-Henseleit buffer solution (143 mM $\mathrm{Na}^{+}, 5.9 \mathrm{mM} \mathrm{K}^{+}, 1.5 \mathrm{mM} \mathrm{Ca}^{2+}, 2.5 \mathrm{mM} \mathrm{Mg}^{2+}, 128 \mathrm{mM}$ $\mathrm{Cl}^{-}, 1.2 \mathrm{mM} \mathrm{H}_{2} \mathrm{PO}_{4}{ }^{2-}, 1.2 \mathrm{mM} \mathrm{SO}_{4}{ }^{2-}, 25 \mathrm{mM} \mathrm{HCO}^{3-}$ and $10 \mathrm{mM} \mathrm{D}$-glucose), continuously equilibrated with $5 \% \mathrm{CO}_{2}$ in $95 \% \mathrm{O}_{2}$ at a $\mathrm{pH}$ of 7.4. Each tracheal segment was mounted on two L-shaped metal prongs. One of the prongs was connected to a force-displacement transducer for continuous recording of isometric tension by Chart software (ADInstruments Ltd, Hastings, U.K.), while the other prong was a displacement device, allowing gentle stretching of the tracheal rings mounted. A basal tension of $0.8 \mathrm{mN}$ was gradually reached over the course of at least $90 \mathrm{~min}$. The segment viabilities were tested using $60 \mathrm{mM} \mathrm{KCl}$. $\mathrm{KCl}$ was later washed out with Kreb-Henseleit buffer solution for three times until the segments reached basal tension. Thereafter, each segment was incubated with $3 \mu \mathrm{M}$ indomethacin for 30 min before administration of agonists to inhibit epithelium-dependent relaxations. Agonists were then administered cumulatively to produce their concentrationeffect curves. To test their relaxant properties, segments were first pre-constricted with $1 \mu \mathrm{M}$ carbachol, and after reaching stable plateaus, the concentration-effect curves for bradykinin- and des-Arg ${ }^{9}$-bradykinin-induced relaxations were produced in the absence of indomethacin.

\section{Real-time quantitative PCR}

After homogenization of the tissues, the total RNA was extracted using the RNeasy Mini kit following the supplier's instructions (QIAGEN GmbH, Hilden, Germany). The purity of total RNA was checked with a spectrophotometer and the wavelength absorption ratio (260/ $280 \mathrm{~nm}$ ) was between 1.7 and 2.0 in all preparations. Reverse transcription of total RNA (0.3-0.4 $\mu \mathrm{g})$ to cDNA was carried out using Omniscript ${ }^{\mathrm{Tm}}$ reverse transcriptase kit (QIAGEN GmbH, Hilden, Germany) in $20 \mu$ l volume reaction at $37^{\circ} \mathrm{C}$ for $1 \mathrm{~h}$ using Mastercycler personal PCR machine (Eppendorf AG, Hamburg, Germany).

Specific primers for murine kinin $B_{1}$ and $B_{2}$ receptors, and the house keeping gene glyceraldehyde-3-phosphate dehydrogenase $(\mathrm{GAPDH})$ were designed using Prime Express 2.0 software (Applied Biosystem, Forster city, CA, USA) and synthesized with DNA Technology A/S (Aarhus, Denmark). The sequences are as following:

Kinin $B_{1}$ receptor [Accession Number: NM_007539]: Forward: 5'-CCA TAG CAG AAA TCT ACC TGG CTA AC-3'; Reverse: 5'-GCC AGT TGA AAC GGT TCC-3'

Kinin $B_{2}$ receptor [Accession Number: NM_009747]: Forward: 5'-ATG TTC AAC GTC ACC ACA CAA GTC3'; Reverse: 5'-TGG ATG GCA TTG AGC CAA C-3'

GAPDH [Accession Number: XM_001473623]: Forward: 5'-CAT GGC CTT CCG TGT TCC TA-3'; Reverse: 5'-TGC TTC ACC ACC TTC TTG ATG-3'

Real-time PCR was performed with QuantiTect ${ }^{\mathrm{Tm}}$ SYBR $^{\oplus}$ Green PCR kit (QIAGEN GmbH, Hilden, Germany) in the Smart Cycler ${ }^{\oplus}$ II system (Cepheid, Sunnyvale, CA, USA). The system automatically monitors the binding of a fluorescent dye $\mathrm{SYBR}^{\odot}$ Green to doublestranded DNA during each cycle of PCR amplification. 
The real-time PCR was prepared in $25 \mu$ l reaction volumes and carried out with heating $95^{\circ} \mathrm{C}$ for $15 \mathrm{~min}$ followed by touchdown PCR i.e. denature at $94^{\circ} \mathrm{C}$ for 30 sec and annealing at $66^{\circ} \mathrm{C}$ for $1 \mathrm{~min}$ for the first PCR cycle, thereafter, a $2^{\circ} \mathrm{C}$ decrease for the annealing temperature in every cycle until $56^{\circ} \mathrm{C}$. Finally, 40 thermal cycles with $94^{\circ} \mathrm{C}$ for $30 \mathrm{sec}$ and $55^{\circ} \mathrm{C}$ for 1 min were performed. The data were analyzed with the threshold cycle $\left(C_{T}\right)$ method and the specificity of the PCR products was checked by the dissociation curves. A blank (no template) was included in all the experiments as negative control. The relative amount of mRNA was expressed as the $C_{T}$ values of mRNA for kinin $B_{1}$ or $B_{2}$ receptor in relation to the $C_{T}$ values for the house-keeping gene GAPDH in the same sample.

\section{Immunohistochemistry with confocal microscopy}

After organ culture, the tracheal segments were immersed in a fixative solution consisting of $4 \%$ paraformaldehyde in $0.1 \mathrm{M}$ phosphate buffer $(\mathrm{pH} 7.4)$ for $3 \mathrm{~h}$ at $4{ }^{\circ} \mathrm{C}$. After fixation, the specimens were dehydrated in $20 \%$ sucrose in $0.1 \mathrm{M}$ phosphate buffer ( $\mathrm{pH} 7.4$ ) for 24 $\mathrm{h}$ at $4^{\circ} \mathrm{C}$, then frozen in Tissue-Tek (Sakura Finetek Europe B.V., Zoeterwoude, Netherlands) and stored at $-80^{\circ}$ C. Sections were cut to $10-\mu \mathrm{m}$-thick slices in a cryostat and mounted on SuperFrost Plus slides (Menzel GMBH \& COKG, Braunschweig, Germany).

Immunohistochemistry were carried out using standard protocols, i.e. the sections were incubated with the primary antibody overnight at $4{ }^{\circ} \mathrm{C}$ and the secondary antibody for $1 \mathrm{~h}$ at room temperature in darkness. Primary and secondary antibodies as well as the dilutions used were as following: kinin $B_{1}$ receptor (1:50, goat, Santa Cruz Biotechnology, Inc. Santa Cruz, CA, USA), kinin $B_{2}$ receptor $(1: 100$, rabbit, Alexis Biochemical, Lausen, Switzerland), phospho-SAPK/JNK (Thr183/ Tyr185) (1:50, rabbit, Cell Signalling Technology, Inc. Beverly, MA, USA), phospho-p38 MAPK (Thr180/ Tyr182) (1:100, rabbit, Cell Signalling Technology) and phospho-ERK1/2 MAPK (Thr202/Tyr204) (1:100, rabbit, Cell Signalling Technology). The appropriate secondary antibodies, goat anti-rabbit IgG H\&L conjugated to fluorescein isothiocynate (FITC) or Texas Red or Alexa Fluor ${ }^{\oplus} 488$ donkey anti-goat IgG H\&L was used for fluorescence microscopic imaging, respectively. In the control experiments, either the primary antibody or the secondary antibody was omitted. The stained specimens were examined under a confocal microscope (Nikon, C1plus, Nikon Instruments Inc., NY, USA). The fluorescence intensity was measured and analysed by Image J software http://rsb.info.nih.gov/ij.

To avoid systemic errors, the nicotine-treated specimen and the corresponding control are always cultured, fixated, stained, examined and scanned at the same time as the same batch, and the setting of the confocal microscope is kept unchanged throughout. This ensures comparability between the groups. The measurements are repeated for each specimen at 6 preset randomly selected sections, at each section the florescence density was measured at 6 areas, and the mean florescence density was obtained from 6 experiments. All measurements are checked and confirmed by another senior researcher.

\section{Reagents}

Bradykinin, des-Arg ${ }^{9}$-bradykinin, sarafotoxin $6 \mathrm{~b}$ and sarafotoxin 6c were purchased from Neosystem S.A., Strasbourg, France. SP600125 (anthrax(1,9-cd)pyrazol-6(2H)one) was from Calbiochem, Bad Soden, Germany. Nicotine, dexamethasone, indomethacin, 5-HT, carbachol, acetylcholine, YM976, theophylline, forskolin, hexamethonium, MG624, DMEM and Krebs-Henseleit buffer were from Sigma, St. Louis, MO, U.S.A. The stock solutions of bradykinin, des-Arg ${ }^{9}$-bradykinin, sarafotoxin $6 \mathrm{~b}$ and sarafotoxin $6 \mathrm{c}$ were prepared in $0.1 \%$ bovine serum albumin. Nicotine, YM976, SP600125, MG624 and forskolin were dissolved in DMSO. Theophylline, hexamethonium, 5-HT, carbachol and acetylcholine were dissolved in distilled water, and indomethacin in 95\% ethanol. All agonists were serially diluted with physiological saline prior to experiments.

\section{Data analysis}

All data were expressed as mean \pm S.E.M. Agonist concentration-effect curve data from individual segments were fitted to the Hill equation using an iterative, leastsquares method (GraphPad Prism 5, San Diego, CA, U. S.A.) to provide estimates of maximal contraction $\left(E_{\max }\right)$ and $\mathrm{pEC}_{50}$ (negative logarithm of the agonist concentration that produces half of its maximal effect). Contractile responses to agonists are all expressed in $\mathrm{mN}$. Concentration-effect curves obtained from myograph studies were compared using two-way analysis of variance (ANOVA) with Bonferroni's post-test. Unpaired student's $t$-test with Welch's correction was used when two groups were compared. $\mathrm{P} \leq 0.05$ was considered to be statistically significant.

\section{Results}

\section{Effects of nicotine on kinin $B_{1}$ and $B_{2}$ receptor-mediated} airway contractions

In order to assess the time-course of nicotine effects on the airway contraction, tracheal segments were organcultured for 1, 2 or 4 days in the presence of nicotine $(10 \mu \mathrm{M})$ or vehicle. A tendency towards an increased airway contractile response to des-Arg ${ }^{9}$-bradykinin and bradykinin was seen already after 2 days of nicotine treatment and this increase reached statistical significance at day 4 (Fig. 1A-F, Table 1). 

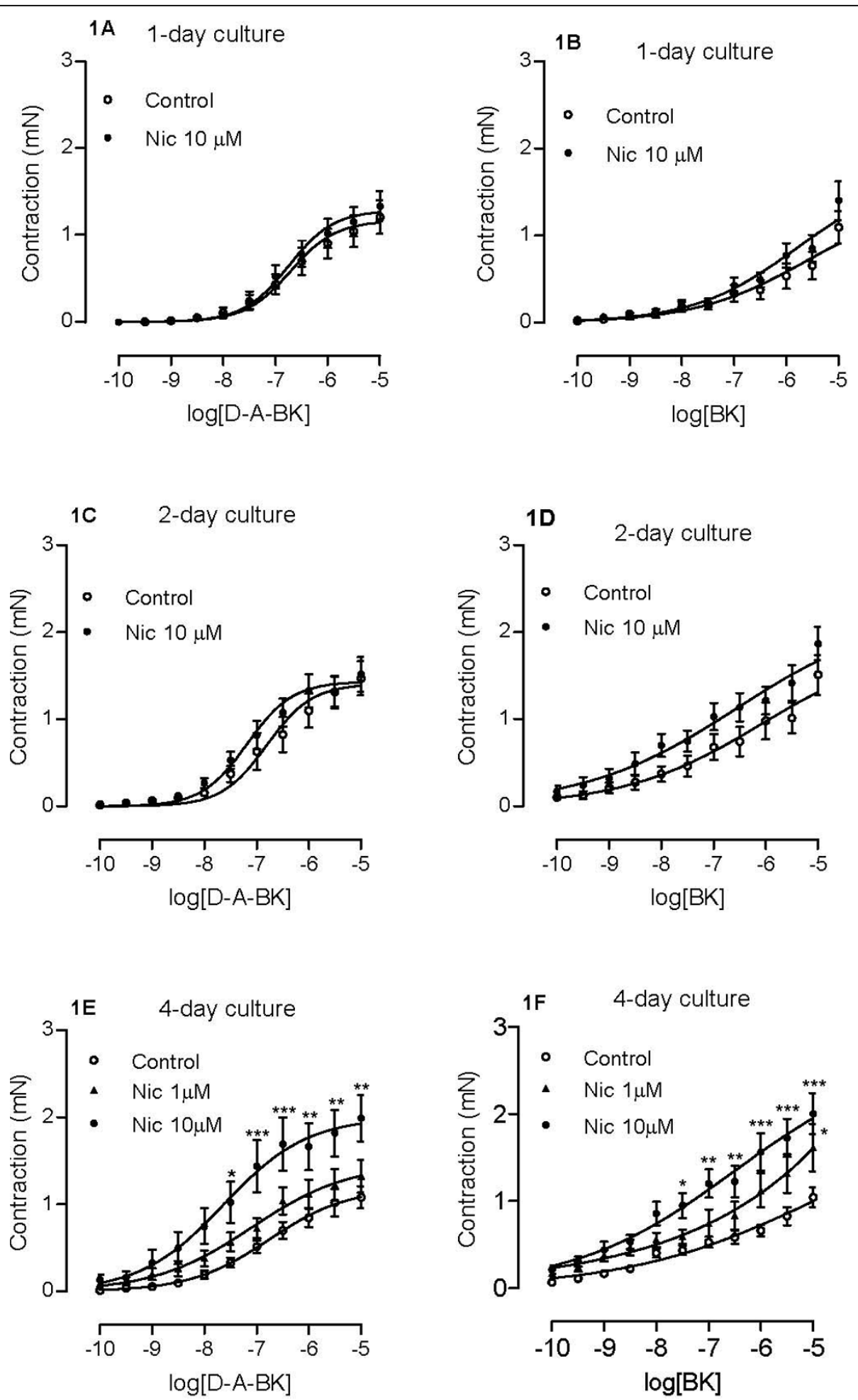

Figure 1 Nicotine-induced effects on kinin receptor-mediated airway contractions. Tracheal segments were cultured for 1 day (A, B), 2 days $(C, D)$ or 4 days $(E, F)$ in presence of vehicle (Control, $0.1 \%$ DMSO) or nicotine (Nic, 1 or $10 \mu \mathrm{M})$. Contractions were induced by des-Arg'bradykinin (D-A-BK; A, C, E) or bradykinin (BK; B, D, F). Each data point is derived from 15-22 experiments and data is presented as mean \pm S.E.M. Statistical analysis was performed using two-way ANOVA with Bonferroni's post-test. Control vs Nic. ${ }^{*} P<0.05 ;{ }^{* *} P<0.01 ;{ }^{* * *} P<0.001$. 
Table 1 Effects of nicotine on des-Arg' ${ }^{9}$-bradykinin- and bradykinin-induced airway contractions

\begin{tabular}{|c|c|c|c|c|c|c|c|}
\hline \multirow[t]{2}{*}{ Incubation time } & \multirow[t]{2}{*}{ Nicotine $(\mu \mathrm{M})$} & \multicolumn{4}{|c|}{ des-Arg ${ }^{9}$-bradykinin } & \multicolumn{2}{|c|}{ Bradykinin } \\
\hline & & $n$ & $E_{\max }(\mathrm{mN})$ & $\mathrm{pEC}_{50}$ & $n$ & $\mathrm{E}_{\max }(\mathrm{mN})$ & $\mathrm{pEC}_{50}$ \\
\hline \multirow[t]{2}{*}{ Day 1} & 0 (Ctrl) & 17 & $1.21 \pm 0.19$ & $6.49 \pm 0.12$ & 15 & $0.99 \pm 0.18$ & $5.81 \pm 0.13$ \\
\hline & 10 & 18 & $1.33 \pm 0.17$ & $6.52 \pm 0.11$ & 16 & $1.29 \pm 0.16$ & $5.79 \pm 0.18$ \\
\hline \multirow[t]{2}{*}{ Day 2} & 0 (Ctrl) & 16 & $1.47 \pm 0.19$ & $6.56 \pm 0.14$ & 17 & $1.51 \pm 0.23$ & $6.15 \pm 0.27$ \\
\hline & 10 & 16 & $1.52 \pm 0.19$ & $6.94 \pm 0.13$ & 17 & $1.86 \pm 0.19$ & $6.75 \pm 0.35$ \\
\hline \multirow[t]{3}{*}{ Day 4} & 0 (Ctrl) & 18 & $1.16 \pm 0.13$ & $6.96 \pm 0.19$ & 21 & $1.40 \pm 0.20$ & $6.72 \pm 0.38$ \\
\hline & 1 & 16 & $1.89 \pm 0.26$ & $6.28 \pm 0.50$ & 19 & $2.10 \pm 0.34$ & $6.57 \pm 0.36$ \\
\hline & 10 & 21 & $2.04 \pm 0.25 * *$ & $7.20 \pm 0.20$ & 22 & $2.18 \pm 0.26 *$ & $7.30 \pm 0.25$ \\
\hline
\end{tabular}

Tracheal segments were cultured for 1,2 or 4 days in presence of vehicle $\left(0.1 \%\right.$ DMSO, Ctrl) or nicotine $(1$ or $10 \mu \mathrm{M})$. $\mathrm{E}_{\max }$ and $\mathrm{pEC} \mathrm{C}_{50}$ for des-Arg ${ }^{9}$-bradykinin and bradykinin are presented as mean \pm S.E.M. Statistical analysis was performed using unpaired student's $t$-test with Welch's correction. Nicotine vs. Ctrl (DMSO). ${ }^{*} P$ $<0.05,{ }^{* *} \mathrm{P}<0.01 . \mathrm{n}=$ number of experiments performed.

Concentration-effects of nicotine were tested on the tracheal segments after 4-day culture. A lower nicotine concentration $(1 \mu \mathrm{M})$ did not significantly increase contractile responses to des- $\mathrm{Arg}^{9}$-bradykinin and bradykinin. Culture with $10 \mu \mathrm{M}$ of nicotine significantly increased the $\mathrm{E}_{\max }$ for both agonists. Although a tendency towards an increased $\mathrm{pEC}_{50}$ can be seen, it did not reach statistical significance (Fig. 1E-F, Table 1). Nicotine $(1$ or $10 \mu \mathrm{M})$ treatment for 1,2 or 4 days did not affect the contractile response mediated by 5 -HT, cholinergic (Table 2) or endothelin receptors (Table 3).

\section{Effects of nicotine on kinin $B_{1}$ and $B_{2}$ receptor-mediated airway relaxations}

Bradykinin and des-Arg ${ }^{9}$-bradykinin can also produce relaxant effects on preconstricted tracheal segments. This relaxation is dependent on the airway epithelium as well as on COX activity and EP receptors [21]. Pretreatment of the segments with COX-inhibitor indomethacin for 30 min makes it possible to study receptor-mediated contractions, as described in Figure 1. Absence of indomethacin allows characterization of kinin-induced relaxations succeeding pre-contraction of the segments with carbachol (1 $\mu \mathrm{M})$. After 4 days of organ culture with nicotine $(10 \mu \mathrm{M})$ or vehicle (0.1\% DMSO), neither $\mathrm{B}_{1}$ nor $\mathrm{B}_{2}$ receptormediated relaxations are affected by nicotine (Fig. 2A-B).
Effects of nicotinic receptor antagonists on nicotineenhanced kinin $B_{1}$ and $B_{2}$ receptor-mediated airway contractions

Neuronal nicotinic acetylcholine receptors can very roughly be divided into two groups: $\alpha$-bungarotoxin-sensitive receptors that contain the $\alpha 7$ subunit and $\alpha$-bungarotoxin-insensitive receptors. MG624 is a specific antagonist for the $\alpha 7$ subunit [24], while hexamethonium inhibits $\alpha$ bungarotoxin-insensitive receptors [25]. In order to find out if the observed nicotine effects on $B_{1}$ and $B_{2}$ receptormediated contractions are mediated through nicotinic receptors, tracheal segments were cultured with $10 \mu \mathrm{M}$ nicotine in combination with either MG624 (100 nM) or hexamethonium ( 1 or $10 \mu \mathrm{M})$. Results show that MG624 completely revoked the enhanced contractions caused by nicotine for both kinin receptors without altering the contractile response in the control group (0.1\% DMSO) at all (Fig. 3A-B). In analogy, hexamethonium $(10 \mu \mathrm{M})$ also depressed the nicotine-enhanced kinin effects (Fig. 3C-D). Applying the same hexamethonium concentration to the DMSO-treated control segments did not cause a decrease in contractile responses for $B_{1}$ and $B_{2}$ receptors, but rather a weak tendency towards increased contraction (Fig. 3EF). Altogether, the results suggest a clear involvement of neuronal nicotinic receptors in nicotine-induced effects on $B_{1}$ and $B_{2}$ receptor-mediated contractions in airways.

Table 2 Effects of nicotine on 5-HT- and acetylcholine-induced airway contractions

\begin{tabular}{|c|c|c|c|c|c|c|c|}
\hline \multirow[t]{2}{*}{ Incubation time } & \multirow[t]{2}{*}{ Nicotine $(\mu \mathrm{M})$} & \multicolumn{4}{|c|}{ 5-HT } & \multicolumn{2}{|c|}{ Acetylcholine } \\
\hline & & $n$ & $E_{\max }(m N)$ & $\mathrm{pEC}_{50}$ & $n$ & $E_{\max }(\mathrm{mN})$ & $\mathrm{pEC}_{50}$ \\
\hline \multirow[t]{2}{*}{ Day 1} & $0(\mathrm{Ctrl})$ & 9 & $1.87 \pm 0.32$ & $6.47 \pm 0.13$ & 8 & $5.81 \pm 0.74$ & $6.51 \pm 0.12$ \\
\hline & 10 & 10 & $1.97 \pm 0.26$ & $6.45 \pm 0.10$ & 8 & $6.20 \pm 0.62$ & $6.46 \pm 0.07$ \\
\hline \multirow[t]{2}{*}{ Day 2} & 0 (Ctrl) & 11 & $2.01 \pm 0.29$ & $6.83 \pm 0.09$ & 8 & $6.45 \pm 0.70$ & $6.57 \pm 0.06$ \\
\hline & 10 & 12 & $1.99 \pm 0.31$ & $6.87 \pm 0.09$ & 8 & $5.95 \pm 0.73$ & $6.56 \pm 0.10$ \\
\hline \multirow[t]{3}{*}{ Day 4} & $0(\mathrm{Ctrl})$ & 10 & $2.01 \pm 0.23$ & $6.98 \pm 0.08$ & 6 & $6.04 \pm 1.05$ & $6.43 \pm 0.07$ \\
\hline & 1 & 9 & $1.89 \pm 0.28$ & $7.00 \pm 0.13$ & 6 & $5.24 \pm 0.64$ & $6.56 \pm 0.12$ \\
\hline & 10 & 8 & $1.88 \pm 0.18$ & $6.89 \pm 0.18$ & 6 & $5.70 \pm 0.49$ & $6.61 \pm 0.11$ \\
\hline
\end{tabular}

Tracheal segments were cultured for 1,2 or 4 days in presence of vehicle (0.1\% DMSO, Ctrl) or nicotine (1 or $10 \mu \mathrm{M})$. $\mathrm{E}_{\mathrm{max}}$ and $\mathrm{pEC} \mathrm{C}_{50}$ for 5 -HT and acetylcholine are presented as mean \pm S.E.M. Statistical analysis was performed using unpaired student's $t$-test with Welch's correction. Nicotine vs Ctrl (DMSO). No significant differences were found between the two groups. $\mathrm{n}=$ number of experiments performed. 
Table 3 Effects of nicotine on endothelin receptor-mediated airway contractions

\begin{tabular}{|c|c|c|c|c|c|c|c|}
\hline \multirow[t]{2}{*}{ Incubation time } & \multirow[t]{2}{*}{ Nicotine $(\mu \mathrm{M})$} & \multicolumn{4}{|c|}{$\mathrm{ET}_{\mathrm{A}}$} & \multicolumn{2}{|c|}{$\mathrm{ET}_{\mathrm{B}}$} \\
\hline & & $n$ & $\mathrm{E}_{\max }(\mathrm{mN})$ & $\mathrm{pEC}_{50}$ & $n$ & $E_{\max }(m N)$ & $\mathrm{pEC}_{50}$ \\
\hline \multirow[t]{2}{*}{ Day 1} & 0 (Ctrl) & 10 & $3.61 \pm 0.40$ & $7.52 \pm 0.14$ & 9 & $3.49 \pm 0.68$ & $8.00 \pm 0.13$ \\
\hline & 10 & 10 & $3.40 \pm 0.33$ & $7.50 \pm 0.07$ & 10 & $3.52 \pm 0.53$ & $7.89 \pm 0.07$ \\
\hline \multirow[t]{2}{*}{ Day 2} & 0 (Ctrl) & 4 & $3.74 \pm 0.87$ & $7.40 \pm 0.20$ & 4 & $3.33 \pm 0.34$ & $8.24 \pm 0.13$ \\
\hline & 10 & 4 & $4.22 \pm 0.85$ & $7.52 \pm 0.11$ & 4 & $3.15 \pm 0.60$ & $8.00 \pm 0.13$ \\
\hline \multirow[t]{3}{*}{ Day 4} & $0(C t r l)$ & 9 & $4.32 \pm 0.71$ & $7.81 \pm 0.10$ & 9 & $4.31 \pm 0.73$ & $8.05 \pm 0.09$ \\
\hline & 1 & 9 & $4.13 \pm 0.42$ & $7.74 \pm 0.07$ & 9 & $4.03 \pm 0.46$ & $8.17 \pm 0.13$ \\
\hline & 10 & 8 & $4.67 \pm 0.37$ & $7.86 \pm 0.10$ & 8 & $4.47 \pm 0.38$ & $8.18 \pm 0.12$ \\
\hline
\end{tabular}

Tracheal segments were cultured for 1,2 or 4 days in presence of vehicle (0.1\% DMSO, Ctrl) or nicotine (1 or $10 \mu \mathrm{M})$. $\mathrm{ET}_{\mathrm{A}}$ : endothelin receptor type $\mathrm{A}_{\text {; }} \mathrm{ET}_{\mathrm{B}}$ : endothelin receptor type $B$. Responses of $\mathrm{ET}_{B}$ receptors were tested with the selective $\mathrm{ET}_{\mathrm{B}}$ agonist sarafotoxin $6 \mathrm{C}$, while responses to $\mathrm{ET}_{\mathrm{A}}$ receptors were tested with the non-selective ET-receptor agonist sarafotoxin $6 \mathrm{~b}$ after the desensitization of $\mathrm{ET}_{\mathrm{B}}$ receptors [39]. $\mathrm{E}_{\max }$ and pEC $\mathrm{C}_{50}$ are presented as mean $\pm \mathrm{S} . \mathrm{E} . \mathrm{M}$. Statistical analysis was performed using unpaired student's $t$-test with Welch's correction. Nicotine vs Ctrl (DMSO). No significant differences were found between the two groups. $\mathrm{n}=$ number of experiments performed.

\section{Effects of nicotine on airway kinin $B_{1}$ and $B_{2}$ receptor mRNA and protein expressions}

The relative amount of mRNA for kinin $B_{1}$ and $B_{2}$ receptors was quantified by real-time PCR. Four days of organ culture in the presence of nicotine $(10 \mu \mathrm{M})$ increased the mRNA expression for both receptors, compared to control (Fig. 4A). The corresponding protein expression was examined using confocal-microscopy-based immunohistochemistry. An increase in kinin $\mathrm{B}_{1}$ (Fig. 5A-B) and $\mathrm{B}_{2}$ (Fig. 5C-D) receptor protein expressions were seen in both the airway epithelial and smooth muscle cells (Fig. 5E-F). In the control segments, the expression of $B_{1}$ receptors is higher in the epithelial cells compared to the smooth muscle cells; while after nicotine treatment, the increase in $B_{1}$ receptor protein expression was more prominent in the smooth muscle cells than in the epithelial cells (Fig. 5E). For $B_{2}$ receptors, their expressions in the control segments are similar between epithelial cells and smooth muscle cells; while after nicotine treatment, $B_{2}$ receptors are expressed more in the epithelial cells than the smooth muscle cells (Fig. 5F).

Intracellular MAPK signal transduction mechanism studies To explore the underlying intracellular signal transduction mechanisms behind the reported nicotine effects on airway kinin receptors, the activation (phosphorylation) of JNK, ERK1/2 and p38 signal molecules were studied with confocal-microscopy-based immunohistochemistry. After 4 days of organ culture with nicotine $(10 \mu \mathrm{M})$, an activation of JNK was observed in the airway epithelial and in smooth muscle cells compared to control (Fig. $6 \mathrm{~A}-\mathrm{B})$. This increase was most marked in the smooth muscle cells (Fig. 6G). In the control segments, the expression of phosphorylated ERK1/2 (Fig. 6C) and p38 (Fig. 6E) was more abundant in the tracheal epithelium
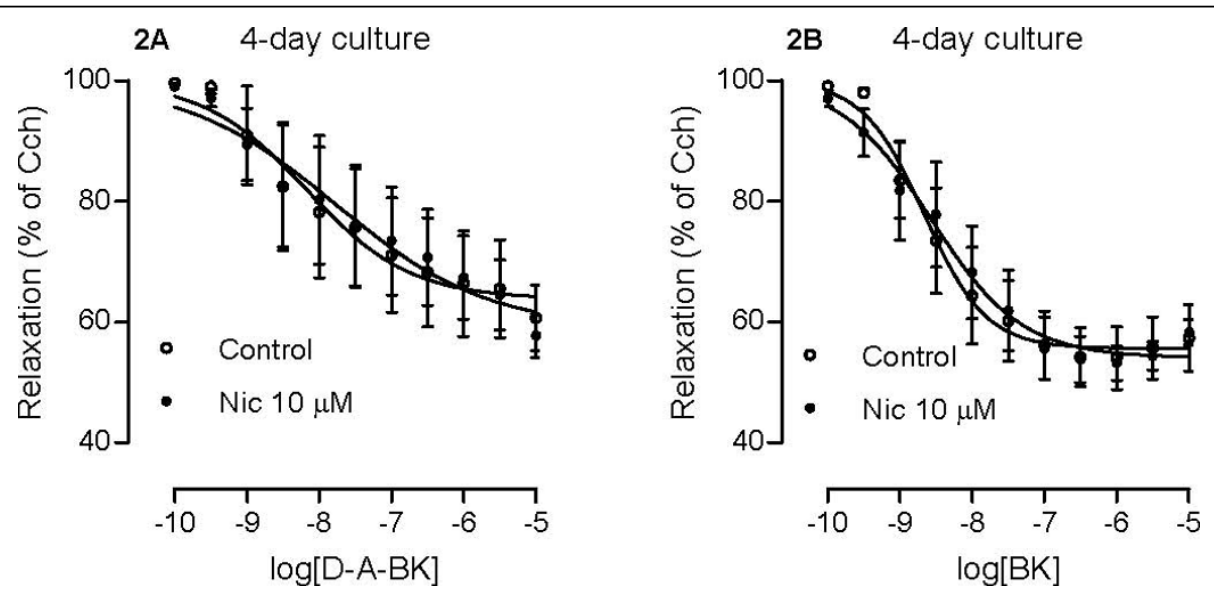

Figure 2 Nicotine-induced effects on kinin receptor-mediated airway relaxations. Tracheal segments were cultured for 4 days in presence of vehicle (Control, $0.1 \% \mathrm{DMSO}$ ) or nicotine (Nic, $10 \mu \mathrm{M}$ ). Relaxations were induced by des-Arg ${ }^{9}$-bradykinin (D-A-BK; A) or bradykinin (BK; B) after pre-constriction with carbachol $(1 \mu \mathrm{M})$. Each data point is derived from 6-8 experiments and data is presented as mean \pm S.E.M. Statistical analysis was performed using two-way ANOVA with Bonferroni's post-test. Control vs Nic. No significant differences were found between the two groups. 

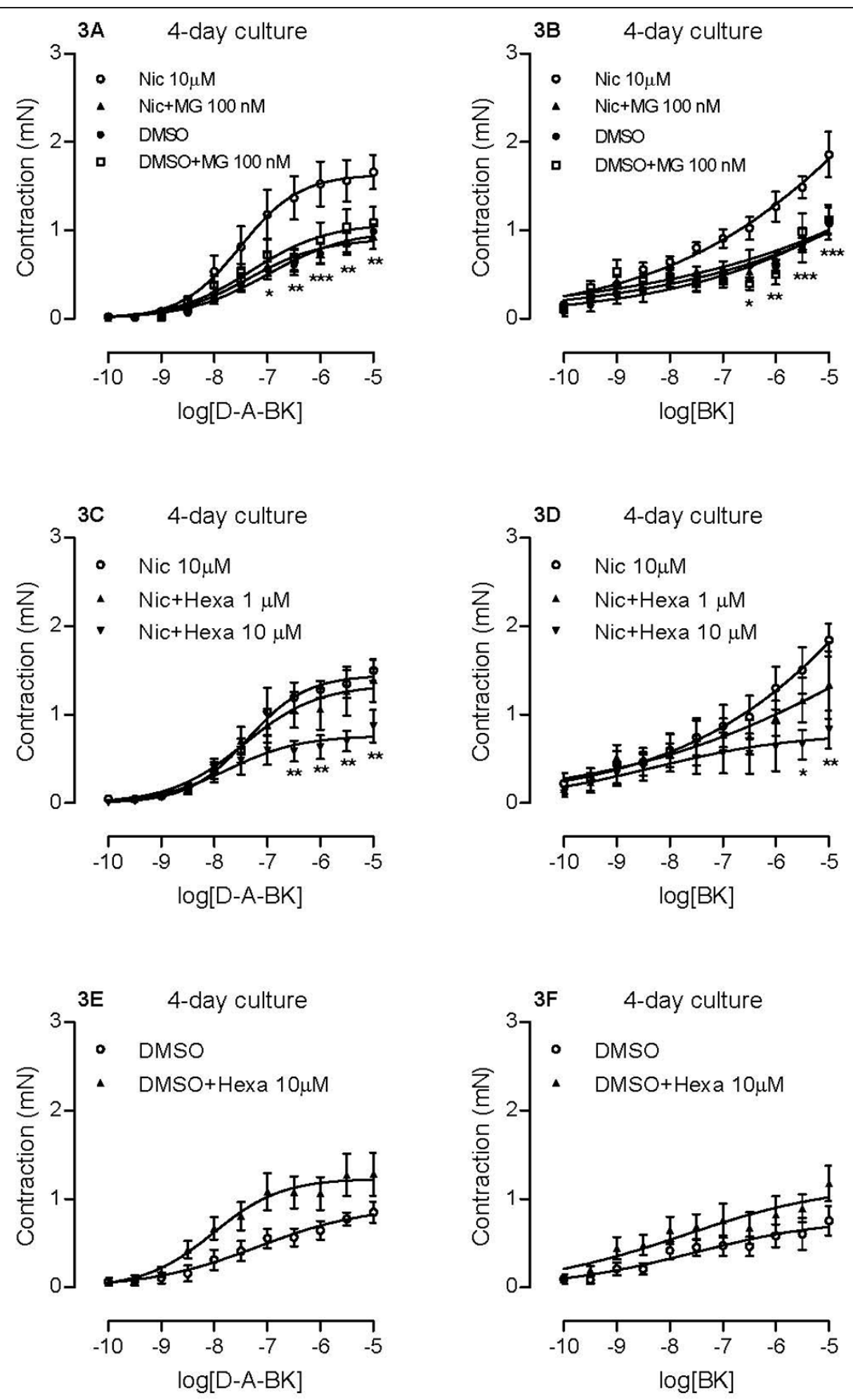

Figure 3 Effects of neuronal nicotinic receptor antagonists on nicotine-enhanced kinin $B_{1}$ and $B_{2}$ receptor-mediated contractions Tracheal segments were cultured for 4 days in presence of vehicle (DMSO, 0.1\%) or nicotine (Nic, $10 \mu \mathrm{M})$ with/without neuronal nicotinic receptor antagonist MG624 (MG, 100 nM, A, B) or hexamethonium (Hexa, 1 or $10 \mu \mathrm{M}, \mathrm{C}-\mathrm{F})$. Contractions were induced by des-Arg9-bradykinin (D-A-BK; A, C, E) or bradykinin (BK; B, D, F). Each data point is derived from 3-6 experiments and data is presented as mean \pm S.E.M. Statistical analysis was performed using two-way ANOVA with Bonferroni's post-test. Nic vs Nic+MG/Hexa (A-D), DMSO vs DMSO+MG/Hexa (A, B, E, F). ${ }^{*} \mathrm{P}<0.05 ;{ }^{* *} \mathrm{P}<0.01 ;{ }^{* * *} \mathrm{P}<0.001$. 

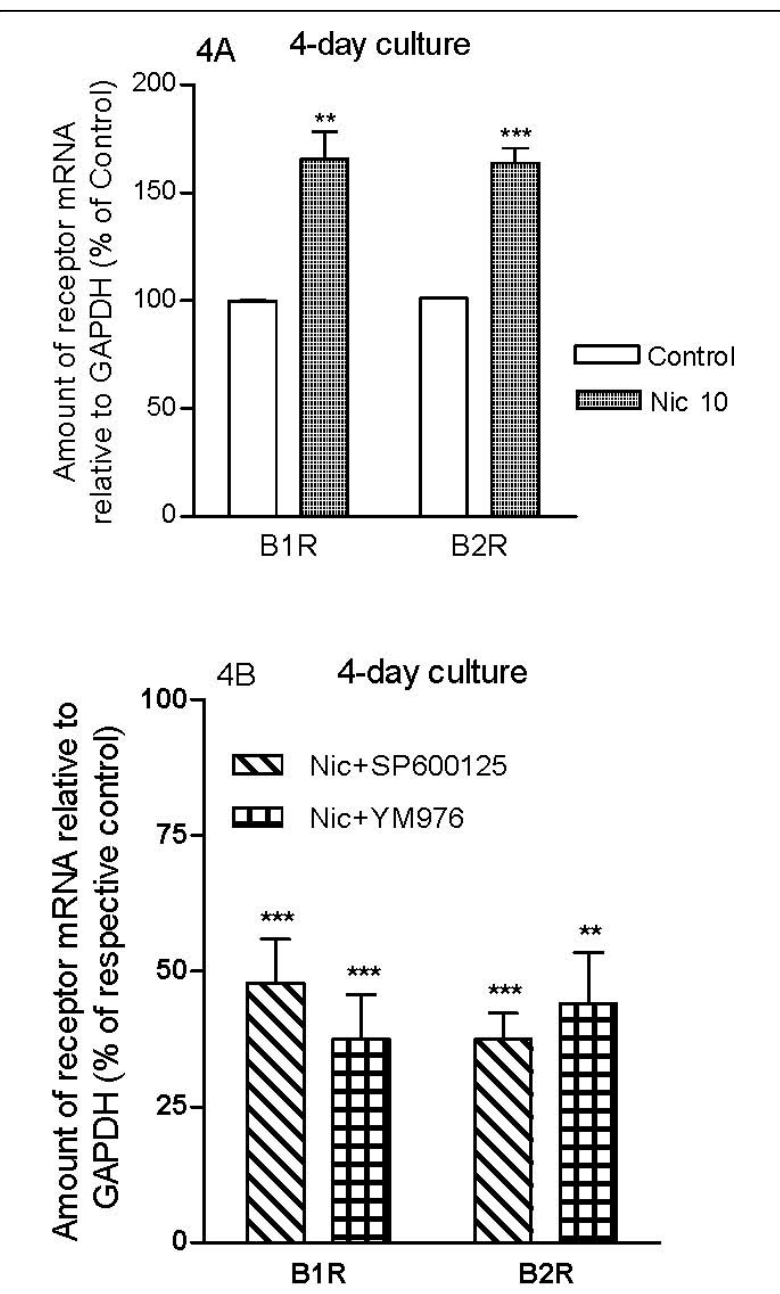

Figure 4 Kinin $B_{1}(B 1 R)$ and $B_{2}(B 2 R)$ receptor mRNA expression. Tracheal segments were cultured for 4 days in presence of vehicle (DMSO, control) or nicotine (Nic, $10 \mu \mathrm{M})(\mathrm{A})$. JNK inhibitor SP600125 or PDE4 inhibitor YM976 was added to 4-day culture with nicotine $(10 \mu \mathrm{M})(\mathrm{B})$. Each data point is derived from 3-6 experiments and data is presented as mean \pm S.E.M. Statistical analysis was performed using unpaired student's $t$-test with Welch's correction. Control vs Nic (A); Nic vs Nic+SP600125/YM976 (B). ** $P<0.01$; ** $P<0.001$.

than smooth muscle cells (Fig. 6H-I). However, in contrast to JNK, no significant differences in ERK1/2 (Fig. 6C, D, H) or p38 (Fig. 6E, F, I) activities were found between the specimen treated with nicotine $(10 \mu \mathrm{M})$ for 4 days and the control (DMSO).

In order to link the activation of JNK to nicotineinduced up-regulation of kinin $B_{1}$ and $B_{2}$ receptors, a specific JNK inhibitor SP600125 $(10 \mu \mathrm{M})$ was added together with nicotine during the 4 days of culture. Pharmacological inhibition of JNK abolished the nicotineenhanced kinin $B_{1}$ and $B_{2}$ receptor-mediated contractions (Fig. 7A-B) and decreased the nicotine-enhanced kinin $B_{1}$ and $B_{2}$ receptor mRNA expressions (Fig. 4B).

\section{Effects of dexamethasone and PDE inhibition}

Dexamethasone is a potent glucocorticoid and wellknown anti-inflammatory drug. Administration of dexamethasone $(1 \mu \mathrm{M})$ together with nicotine in the organ culture for 4 days almost completely abolished the nicotine-enhanced airway contractions to both des-Arg ${ }^{9}$-bradykinin (Fig. 7C) and bradykinin (Fig. 7D).

To explore the role of PDE in nicotine-enhanced contractile response to the kinins, PDE inhibitors YM976 and theophylline were applied. Theophylline is a nonselective PDE inhibitor, while YM976 is a specific inhibitor for PDE4. The latter PDE subtype is specific for cAMP and thought to be of importance for asthmatic inflammation [26]. After 4 days of treatment with the PDE inhibitors, YM976 concentration-dependently attenuated nicotine up-regulated $B_{1}$ receptor-mediated contractions (Fig. 8C), whereas the dose-relation was less obvious for contractions mediated via $\mathrm{B}_{2}$ receptors (Fig. $8 \mathrm{D})$. Contractile responses of the control (DMSO) segments were unaffected by YM976 (Fig. 8E-F). The decrease in receptor-mediated contractions is paralleled with a significant decrease in nicotine-enhanced kinin $B_{1}$ and $B_{2}$ receptor mRNA expression shown by realtime PCR (Fig. 4B). Theophylline exhibited similar effects as YM976, effectively attenuating both $B_{1}$ and $B_{2}$ receptor-mediated airway contractions. The theophylline effect is clearly concentration-dependent (Fig. 8A-B).

\section{Effects of cAMP}

Forskolin is an adenylyl-cyclase activator and raises the level of intracellular cAMP. YM976 inhibits PDE4, the enzyme responsible for the breakdown of cAMP, which in turn also causes an increase in intracellular cAMP levels. To test whether elevation of intracellular cAMP levels is responsible for the PDE inhibitors' ability to attenuate nicotine-enhanced $B_{1}$ and $B_{2}$ receptormediated contraction, we treated the segments with forskolin $(10 \mu \mathrm{M})$ for 4 days in the absence or presence of nicotine $(10 \mu \mathrm{M})$. Results show that forskolin suppresses contractions induced by both bradykinin and des-Arg ${ }^{9}$ bradykinin, and this is regardless of the presence or absence of nicotine (Fig. 9A-B).

\section{Discussion}

Cigarette smoke is associated with chronic airway inflammation, AHR, increased asthma severity and to a certain degree, asthma development in children [1-7]. Chronic exposure to tobacco smoke increases AHR to bradykinin in vivo [8]. The presented study demonstrated for the first time that long-term exposure (for 4 days) of mouse tracheal segments to nicotine causes a concentration-dependent increase of kinin $B_{1}$ and $B_{2}$ receptor-mediated airway contractions. Since $B_{1}$ and $B_{2}$ receptor-mediated relaxation remained unaffected, the 

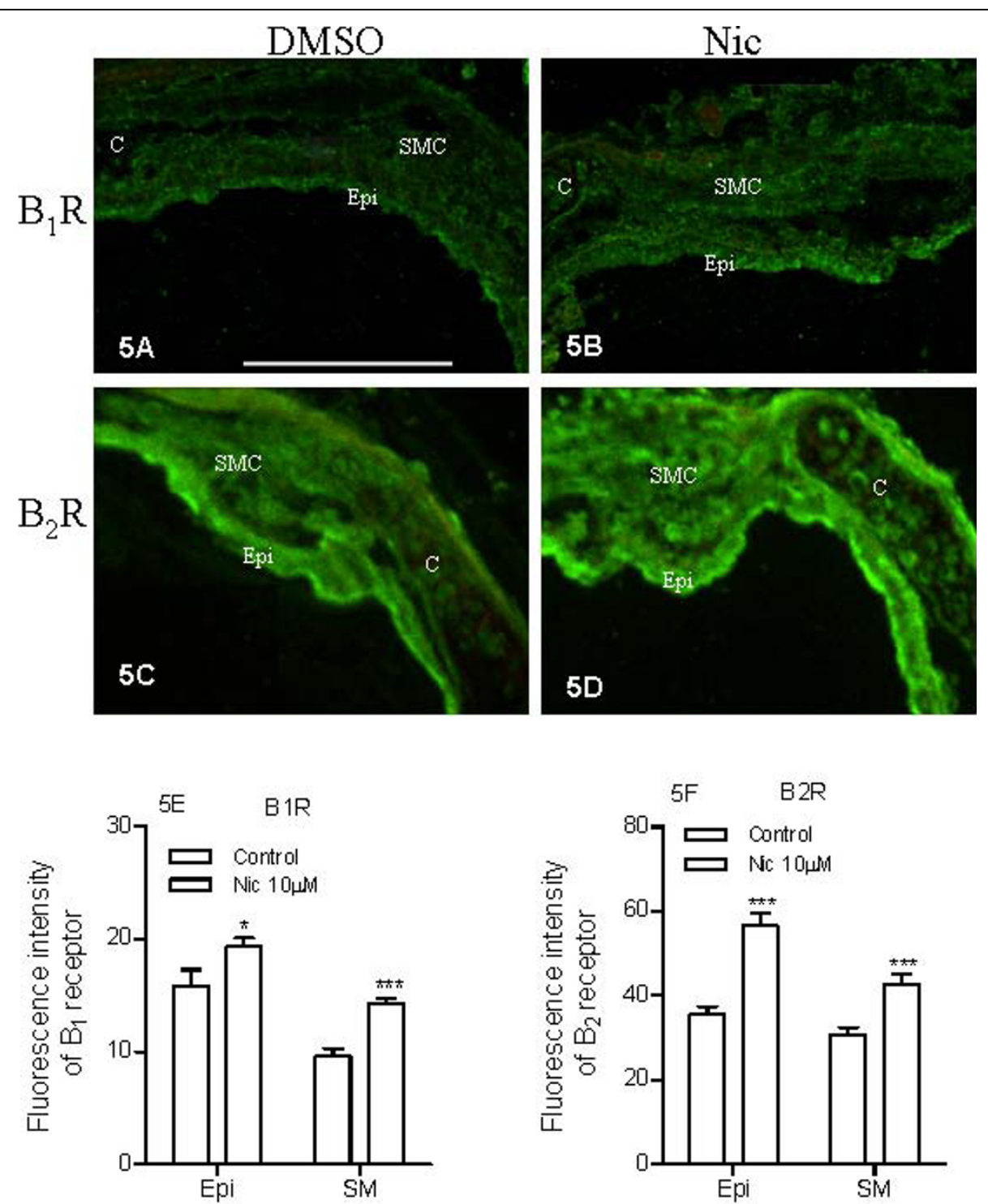

Figure 5 Nicotine-induced effects on kinin $B_{1}(B 1 R)$ and $B_{2}(B 2 R)$ receptor protein expression. Tracheal segments were cultured for 4 days in presence of vehicle (DMSO, A, C) or nicotine (Nic, $10 \mu \mathrm{M}, \mathrm{B}, \mathrm{D})$. The reference bar corresponds to $25 \mu \mathrm{m}$. The intensity of fluorescence was semi-quantified using Image J software (E, F). Epi = epithelium; SMC = smooth muscle cells; and C = cartilage. Each data point is derived from 6 experiments. Two-tailed unpaired Student's $t$-test with Welch's correction was preformed. Control vs Nic. ${ }^{*} P<0.05$; ${ }^{* * *} P<0.001$.

resulting netto effect is an increase in contraction. Short-term nicotine exposure (for 1 - 2 days) induced no significant effects. Neither did nicotine treatment affect airway contractions mediated by 5 -HT, cholinergic or endothelin receptors. The increase in maximal contraction, without significant change of $\mathrm{pEC}_{50}$, seen after 4 days of nicotine treatment suggests an increase in kinin receptor protein expression rather than alteration of receptor sensitivity. This conclusion is further supported by the discovery of an up-regulated protein expression for both $B_{1}$ and $B_{2}$ receptors using confocal microscopy. In addition, real-time PCR reveals a parallel increase in $B_{1}$ and $B_{2}$ receptor mRNA suggesting the involvement of transcriptional mechanisms in nicotine's effects. The neuronal nicotinic receptor antagonists MG624 and hexamethonium both abolish the nicotineenhanced kinin effect, signifying the participation of nicotinic receptors in the start of the process. Further, the intracellular cascade related to the kinin receptor up-regulation seems to involve JNK- and PDE4-related intracellular signal pathways.

Neuronal nicotinic receptors in non-neuronal cells have been proposed to be mediators of tobacco toxicity since they are considered to have a "hormone-like" function [27]. Our results show that the neuronal nicotinic receptor antagonists MG624 [24] and hexamethonium [25] both 

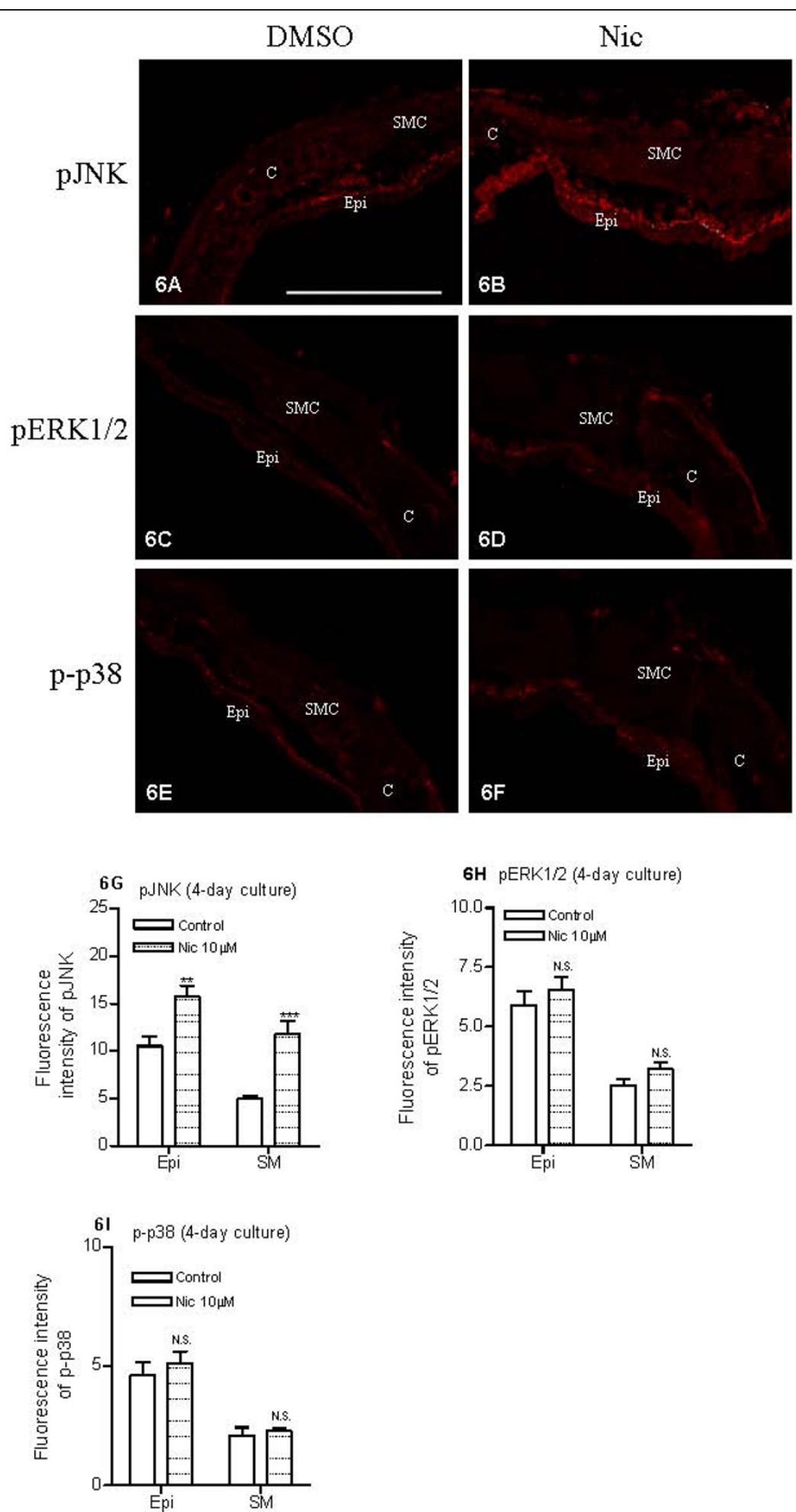

Figure 6 Nicotine-induced effects on phosphorylated JNK (pJNK), ERK1/2 (pERK1/2) and p38 (p-p38) protein expression. Tracheal segments were cultured for 4 days in presence of vehicle (DMSO, A, C, E) or nicotine (Nic, $10 \mu M, B, D$, F). The reference bar corresponds to 25 $\mu \mathrm{m}$. The intensity of fluorescence was semi-quantified by Image J software $(G, H, I)$. Epi = epithelium; SMC = smooth muscle cells; and $\mathrm{C}=$ cartilage. Each data point is derived from 6 experiments. Two-tailed unpaired Student's $t$-test with Welch's correction was preformed. Control vs Nic. ${ }^{* *} P<0.01 ;{ }^{* *} P<0.001$, N.S. $=$ no significance. 

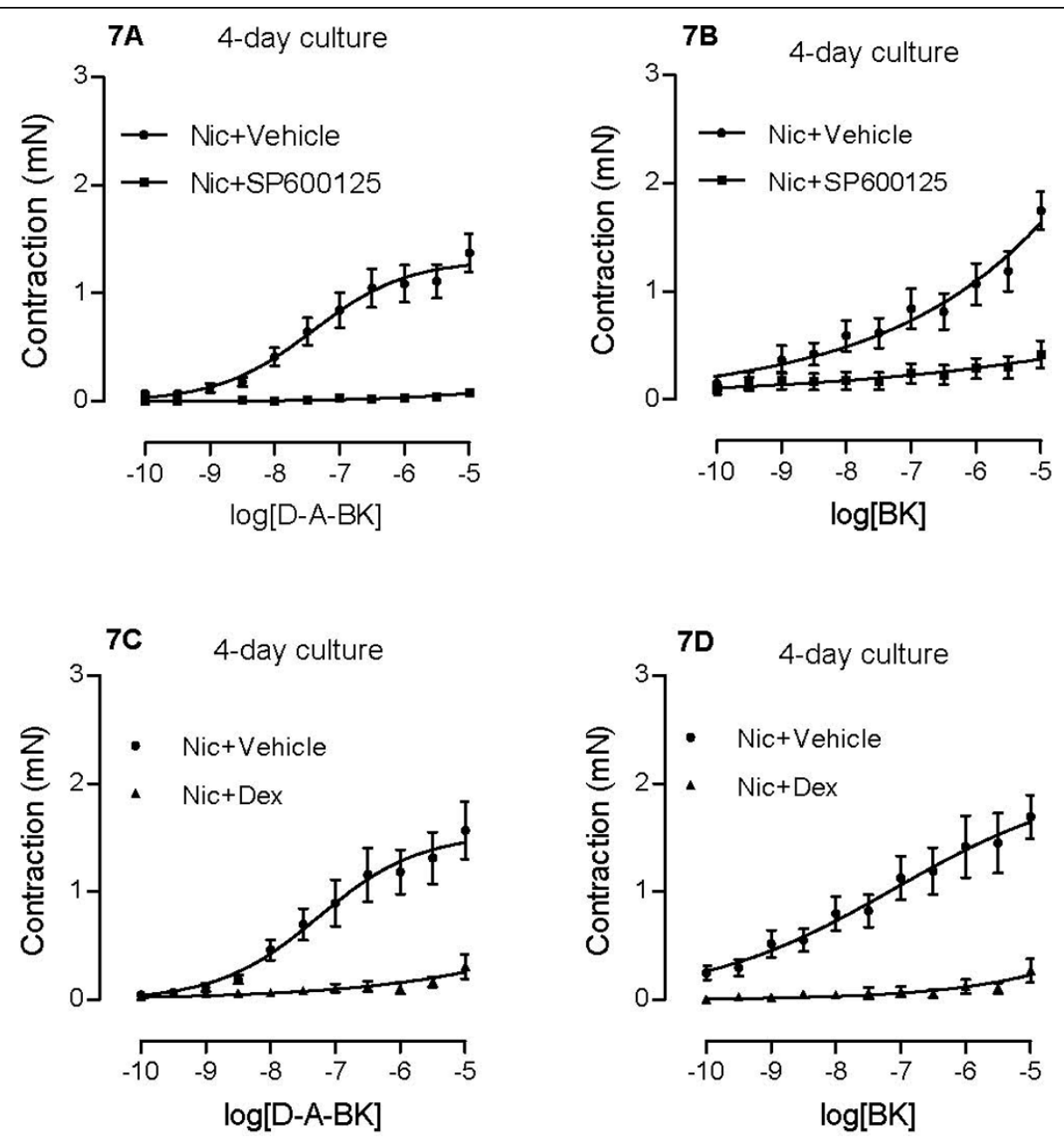

Figure 7 Effects of JNK inhibitor SP600125 $(10 \mu \mathrm{M})$ and dexamethasone (Dex, $1 \mu \mathrm{M})$ on nicotine-enhanced des-Arg ${ }^{9}$-bradykinin- (A, C) and bradykinin- (B, D) induced contractions. Tracheal segments were cultured for 4 days in presence of nicotine (Nic, $10 \mu \mathrm{M})$ together with vehicle or SP600125 (A, B) or dexamethasone (C, D). Each data point is derived from 10-12 experiments.

inhibit nicotine's effects on the kinin receptor-mediated contractions, without suppressing contractions in control segments. In human smokers, nicotine is not only found in blood plasma, but also in saliva and induced sputum. The nicotine concentrations in saliva can be up to $8 \mu \mathrm{M}$ during "smoking days" [28] and 5 min after smoking a cigarette, the induced sputum (not contaminated with saliva) contains a surprising $34 \mu \mathrm{M}$ of nicotine [29]. Therefore, the lungs and bronchial surfaces of smokers might be exposed to a much higher nicotine concentration than that measured in the bloodstream. The concentration that was demonstrated to cause a significant effect in the present study was $10 \mu \mathrm{M}$. The same concentration has previously been shown to cause phosphorylation of the MAPK p44/42, an effect that can be inhibited by nAChR antagonists [30]. Similar nicotine concentrations is also known to induce alteration in the gene-expression of macrophage-like human cell line [31].
Many GPCRs are involved in the regulation of the contractile state of airway smooth muscle, including 5HT, bradykinin, endothelin (type A and type B) and M3 muscarinic acetylcholine receptors. Bradykinin, endothelin and M3 muscarinic receptors are Gq-coupled while 5-HT receptors are Gi-coupled [18]. The presented results show that nicotine up-regulated kinin $B_{1}$ and $B_{2}$ receptor-mediated airway contractions, leaving $5-\mathrm{HT}$, cholinergic and endothelin receptor-mediated contractions completely unaffected. This suggests that nicotine acts on specific targets within the airways. Thus, the effects observed are neither the result of a general hyperresponsiveness nor due to alteration of downstream G-protein signaling processes. This idea is further strengthen by our findings of a simultaneous upregulation of receptor function, mRNA and protein expression. It is known that bradykinin acts as a potent bronchoconstrictor in asthmatic patients, but has no 

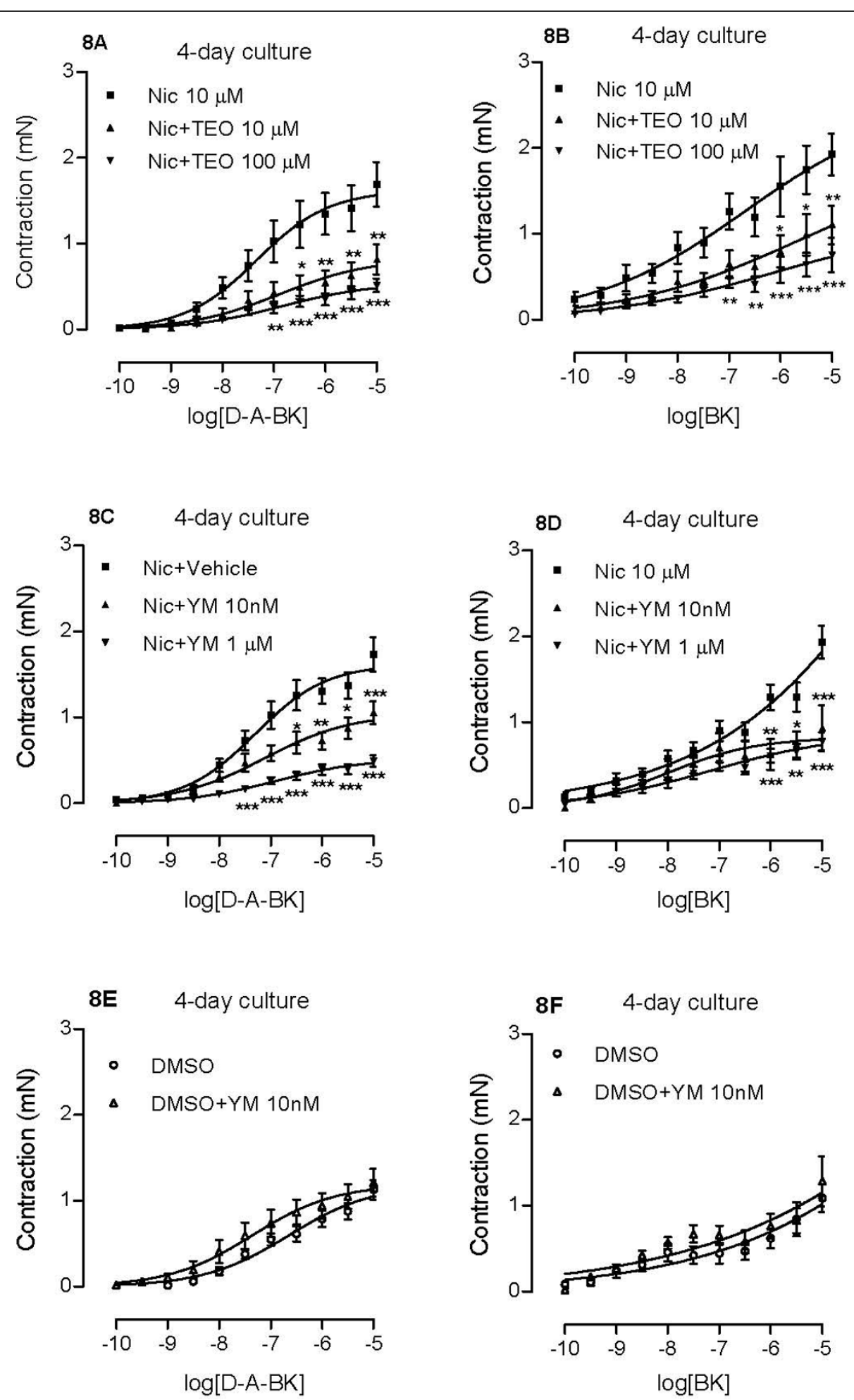

Figure 8 Effects of YM976 (C, D, E, F) and theophylline (A, B) on nicotine-enhanced des-Arg'-bradykinin- (A, C, E) and bradykinin$(\mathbf{B}, \mathbf{D}, \mathbf{F})$ induced contractions. Tracheal segments were cultured for 4 days in absence $(E, F)$ or presence (A-D) of nicotine (Nic, $10 \mu M)$ together with vehicle, YM976 (YM, $1 \mu \mathrm{M}$ or $10 \mathrm{nM}$ ) or theophylline (TEO, 10 or $100 \mu \mathrm{M}$ ). Each data point is derived from 4-17 experiments and presented as mean \pm S.E.M. Statistical analysis was performed using two-way ANOVA with Bonferroni's post-test. Nic vs Nic+TEO (A, B); Nic + vehicle vs Nic+YM (C, D); DMSO vs DMSO+YM $(E, F) .{ }^{*} \mathrm{P}<0.05 ;{ }^{* *} \mathrm{P}<0.01 ;{ }^{* *} \mathrm{P}<0.001$. 

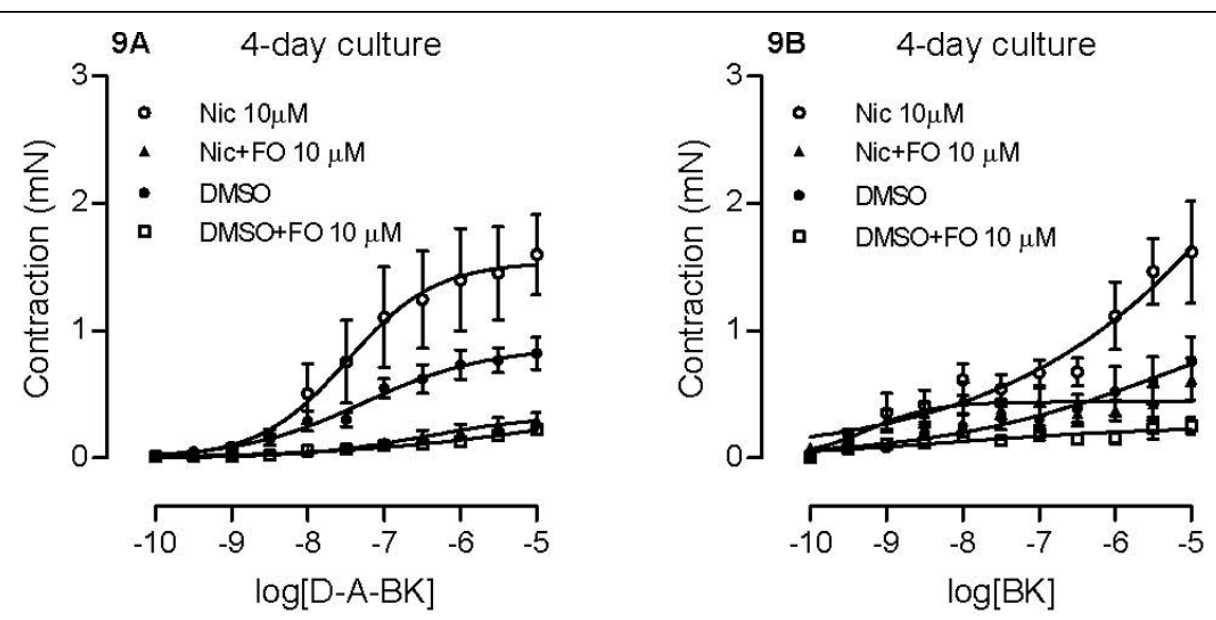

Figure 9 Effects of forskolin on nicotine-enhanced des-Arg ${ }^{9}$-bradykinin- (A) and bradykinin- (B) induced contractions. Tracheal segments were cultured for 4 days in absence (DMSO) or presence of nicotine (Nic, $10 \mu \mathrm{M})$ together with vehicle or forskolin (FO, $10 \mu \mathrm{M})$. Each data point is derived from 3-4 experiments and presented as mean \pm S.E.M.

effect in normal individuals [21]. Many studies have also demonstrated a strong link between allergic inflammation, AHR and bradykinin [32-34]. Further, polymorphism in the $B_{2}$ receptor gene has been found to be associated with asthma prior to the age of 4 [35]. Our results support the importance of bradykinin in AHR and reveal a special role for bradykinin in nicotine- and/ or tobacco smoke-induced AHR.

Stimulation of the kinin receptors can cause both bronchoconstriction and epithelium-dependent relaxations in the airways. It is interesting to note that though kinin receptor protein expression was increased both on the epithelium and smooth muscle, bradykinin- and des-Arg ${ }^{9}$ bradykinin-induced relaxations were unaffected. This might be due to involvement of different pathways. Stimulation of kinin $B_{1}$ and $B_{2}$ receptors on the airway smooth muscle directly activates the inositol 1,4,5-trisphosphate $\left(\mathrm{IP}_{3}\right)$ pathway increasing intracellular $\mathrm{Ca}^{2+}$ levels which subsequently activates the cellular contractile machinery [18]. Kinin receptor-mediated relaxation, on the other hand, is epithelium-dependent. Bradykinin and des-Arg ${ }^{9}$ bradykinin activate COX and stimulate the release of $\mathrm{PGE}_{2}$ from airway epithelial cells which induce airway relaxation through EP receptor activation [21]. Therefore, kinin receptor-mediated relaxations are strongly dependent on intact epithelial functions. Nicotine can damage airway epithelial cells with changes in ionic relations and cause submucosal edema as shown with electron microscopy examination of nicotine-treated rat trachea [36]. This might impair the relaxant functions of airways, disregarding the abundance of kinin receptors.

JNK, ERK $1 / 2$ and $\mathrm{p} 38$ are the classical members of the MAPK family. They are known to play key roles in the regulation of gene expressions. A recent study with human lung macrophages revealed an increase in MAPK phosphorylation and activation of the MAPK/AP-1 pathway caused by cigarette smoke [37]. In another study of human bronchial epithelial cells, ERK1/2, JNK, but not p38 was strongly activated after treatment with nicotine [13]. A special role of JNK in the pathogenesis of asthma has also been implicated [38]. In the present study, nicotine induced activation of JNK, but not ERK1/2 and p38. SP600125 is a small molecular inhibitor for JNK. At the concentration of $10 \mu \mathrm{M}$, SP600125 selectively inhibits the phosphorylation of JNK, but not ERK1/2 or p38 in vessels [39]. Our results show that SP600125 abolished the nicotine-enhanced kinin receptor-mediated contractions and the receptor mRNA expression. These results are well in line with a previous study which has demonstrated that SP600125 exhibits powerful inhibitory effect on TNF- $\alpha$ induced up-regulation of kinin $B_{1}$ and $B_{2}$ receptors in airways [20]. Both bradykinin and des-Arg ${ }^{9}-$ bradykinin elicits only negligible contractile responses in fresh segments and the culture procedure per se causes an up-regulation of the kinin receptors [20]. The $B_{1}$ and $B_{2}$ receptor-mediated contractions were nearly completely abolished by SP600125, suppressing the contractile response to a level similar to that seen in fresh segments [20]. This suggests that both nicotine and the organ culture procedure induce activation of the same intracellular pathway i.e. the MAPK JNK pathway. The increase in $B_{1}$ and $B_{2}$ receptor mRNA and protein expression after organ culture with nicotine strengthens the evidence for an alteration at the receptor level rather than a downstream process. Furthermore, SP600125 up to $30 \mu \mathrm{M}$ causes no alteration in carbachol-elicited contractile 
responses [20], which excludes the possibility of toxic effects of SP600125 on the contractile machinery of the tracheal segments.

Dexamethasone reduces inflammation and hyperreactivity in asthmatic airways $[40,41]$, inhibits kinin receptor expression in cultured human airway fibroblast and smooth muscle cells $[42,43]$. It also suppress both TNF$\alpha$ - and organ culture-induced kinin receptor expression in airway smooth muscle [22]. In line with this, the present data demonstrates that dexamethasone inhibited nicotine-enhanced kinin $B_{1}$ and $B_{2}$ receptor-mediated effects in murine airways. It is interesting to note that the effect of dexamethasone appears to be very similar to those of SP600125. Dexamethasone is classically thought to exert its effects via the inhibition of the proinflammatory transcription factors activator protein-1 (AP-1) and NF- $\kappa$ B [44]. The JNK cascade has long been related to the transcription factor NF- $\kappa \mathrm{B}$ [45] and its ability to bind to AP-1 and form the transcription complex c-JUN/AP-1 is well-known. Nicotine has been reported to activate NF- $\kappa \mathrm{B}$ through phosphorylation of JNK [46]. In addition, cigarette smoke can activate AP-1 also via the MAPK/JNK pathway [37,47]. It is therefore tempting to assume that the presently seen effects of dexamethasone are related to inhibition of transcription factor activation downstream of the JNK pathway. However, it has been recently shown that dexamethasone's intracellular actions are much more complex. They include both inhibition of the upstream negative regulator of JNK and p38 MAPKs called MAP kinase phosphatase-1 [48] and post-transcriptional/translational regulation of gene expressions [42,49].

YM976 is a selective PDE4 inhibitor shown to possess powerful anti-inflammatory and direct broncho-relaxant effects in combination with low emetogenicity [26]. The latter is a common problem with older PDE4 inhibitors. Theophylline is a classical, archetypal, non-specific PDE inhibitor. Both drugs attenuated the enhancement caused by nicotine on kinin $B_{1}$ and $B_{2}$ receptor-mediated airway contractions. Moreover, YM976 also suppresses nicotineenhanced kinin receptor mRNA expression. PDE4 is expressed in airway smooth muscle cells and increases intracellular concentration of the second messenger cAMP [50]. Inhibition of PDE4 suppresses endotoxininduced airway inflammation and hyperreactivity [51], inhibits reactive oxygen species production, cell adhesion molecule expression and the release of cytokines from activated T-helper cells, airway epithelial cells, basophils, monocytes and macrophages [52]. The mechanisms behind the effects of PDE inhibitors might be related to changes in cAMP-dependent inflammatory pathways via a reduction of TNF- $\alpha$-induced expression of RANTES, chemokines and eotaxin in the airway smooth muscle cells [53]. When intracellular cAMP levels were directly raised with the adenylyl cylase activator forskolin, we observed effects similar to those of PDE-inhibitors. The downstream protein kinase PKA has also been reported to be involved in cytokine-stimulated up-regulation of kinin $\mathrm{B}_{2}$ receptors [42]. However, inhibition of PDE4 produces a specific depression of nicotine's effects without altering control, while forskolin depresses contractile responses in both the nicotine and control group. This suggests that the nicotine-induced changes might be PDE4-specific. PDE4 is dependent on cAMP to produce a cellular response. Hence, the ability to enhance intracellular cAMP levels, although disparate for both YM976 and theophylline, might be responsible for their suppression of nicotineenhanced kinin receptor-mediated contractions.

Our results show the simultaneous involvement of both JNK and PDE4/cAMP-mediated pathway in nicotine's effects on kinin receptors. Supporting this, there have been many reports on the "cross-talk" between cAMP and JNK pathway. cAMP has the ability to inhibit JNK activation in human airway smooth muscle cells [54], and in rat renal mesangial cells. Forskolin inhibits MAPK [55]. Activation of ERK5 and the subsequent transcription of c-JUN, but not ERK1/2, can be blocked by cAMP through PKA [17].

To conclude, nicotine has been shown to have the ability to enhance bradykinin- and des-Arg ${ }^{9}$-bradykinininduced airway contractions without affecting their relaxations. The nicotine effect is mediated by activation of airway neuronal nicotinic receptors which results in a transcriptional up-regulation of kinin $B_{1}$ and $B_{2}$ receptors. The whole process depends on the activation of JNK- and PDE4-related intracellular signal pathways Thus, our findings might provide new therapeutic targets for future treatment of tobacco smoke-associated AHR.

\section{Acknowledgements}

The authors are grateful to Ingegerd Larsson for RNA isolation. The present work was supported by Swedish Medical Research Council, Swedish Heart Lung Foundation, Swedish Association for Allergology, and Swedish Foundation for Health Care Science and Allergic Research.

\section{Authors' contributions}

YX carried out the experiments and data analysis, participated in design of the study and drafted the manuscript. YZ conceived and designed the study, helped with performing the immunohistological studies and drafting the manuscript. LOC supervised the work and provided intellectual input in the study. All authors contributed in writing the manuscript and approved the final version.

\section{Competing interests}

The authors declare that they have no competing interests.

Received: 3 November 2009

Accepted: 29 January 2010 Published: 29 January 2010

\section{References}

1. Trigg CJ, Bennett JB, Tooley M, Sibbald B, D'Souza MF, Davies RJ: A general practice based survey of bronchial hyperresponsiveness and its relation to symptoms, sex, age, atopy, and smoking. Thorax 1990, 45(11):866-872. 
2. Higgins BG, Britton JR, Chinn S, Lai KK, Burney PG, Tattersfield AE: Factors affecting peak expiratory flow variability and bronchial reactivity in a random population sample. Thorax 1993, 48(9):899-905.

3. Menon P, Rando RJ, Stankus RP, Salvaggio JE, Lehrer SB: Passive cigarette smoke-challenge studies, increase in bronchial hyperreactivity. $J$ Allergy Clin Immunol 1992, 89(2):560-566.

4. Janson C, Chinn S, Jarvis D, Zock JP, Toren K, Burney P: Effect of passive smoking on respiratory symptoms, bronchial responsiveness, lung function, and total serum IgE in the European Community Respiratory Health Survey, a cross-sectional study. Lancet 2001, 358(9299):2103-2109.

5. Strachan D, Cook D: Health effects of passive smoking. 6. Parental smoking and childhood asthma, longitudinal and case-control studies. Thorax 1998, 53(3):204-212.

6. Illi S, von Mutius E, Lau S, Nickel R, Niggemann B, Sommerfeld C, Wahn U: The pattern of atopic sensitization is associated with the development of asthma in childhood. J Allergy Clin Immunol 2001, 108(5):709-714.

7. Eisner MD, Klein J, Hammond SK, Koren G, Lactao G, Iribarren C: Directly measured second hand smoke exposure and asthma health outcomes. Thorax 2005, 60(10):814-821.

8. Bergren DR: Chronic tobacco smoke exposure increases airway sensitivity to capsaicin in awake guinea pigs. J Appl Physiol 2001, 90(2):695-704.

9. Carlisle DL, Hopkins TM, Gaither-Davis A, Silhanek MJ, Luketich JD, Christie NA, Siegfried JM: Nicotine signals through muscle-type and neuronal nicotinic acetylcholine receptors in both human bronchial epithelial cells and airway fibroblasts. Respir Res 2004, 5:27.

10. Vassallo R, Kroening PR, Parambil J, Kita H: Nicotine and oxidative cigarette smoke constituents induce immune-modulatory and pro-inflammatory dendritic cell responses. Mol Immunol 2008, 45(12):3321-3329.

11. Wang H, Yu M, Ochani M, Amella CA, Tanovic M, Susarla S, Li JH, Wang H, Yang $\mathrm{H}$, Ulloa $\mathrm{L}$, et al: Nicotinic acetylcholine receptor alpha7 subunit is an essential regulator of inflammation. Nature 2003, 421(6921):384-388.

12. Mishra NC, Rir-Sima-Ah J, Langley RJ, Singh SP, Pena-Philippides JC, Koga T, Razani-Boroujerdi S, Hutt J, Campen M, Kim KC, et al: Nicotine primarily suppresses lung Th2 but not goblet cell and muscle cell responses to allergens. J Immunol 2008, 180(11):7655-7663.

13. Tsai JR, Chong IW, Chen CC, Lin SR, Sheu CC, Hwang JJ: Mitogen-activated protein kinase pathway was significantly activated in human bronchial epithelial cells by nicotine. DNA Cell Biol 2006, 25(5):312-322.

14. Fan Chung K: Phosphodiesterase inhibitors in airways disease. Eur $J$ Pharmacol 2006, 533(1-3):110-117.

15. Billington CK, Le Jeune IR, Young KW, Hall IP: A major functional role for phosphodiesterase 4D5 in human airway smooth muscle cells. Am J Respir Cell Mol Biol 2008, 38(1):1-7.

16. Zhang J, Bui T, Xiang J, Lin A: Cyclic AMP inhibits p38 activation via CREB-induced dynein light chain. Mol Cell Biol 2006, 26(4):1223-1234

17. Pearson GW, Earnest S, Cobb MH: Cyclic AMP selectively uncouples mitogen-activated protein kinase cascades from activating signals. Mol Cell Biol 2006, 26(8):3039-3047.

18. Billington CK, Penn RB: Signaling and regulation of G protein-coupled receptors in airway smooth muscle. Respir Res 2003, 4:2.

19. Zhang $Y$, Adner M, Cardell LO: IL-1 beta-induced transcriptional upregulation of bradykinin $B 1$ and $B 2$ receptors in murine airways. Am J Respir Cell Mol Biol 2007, 36(6):697-705.

20. Zhang Y, Adner M, Cardell LO: Up-regulation of bradykinin receptors in a murine in-vitro model of chronic airway inflammation. Eur J Pharmacol 2004, 489(1-2):117-126.

21. Barnes PJ: Bradykinin and asthma. Thorax 1992, 47(11):979-983

22. Zhang Y, Adner M, Cardell LO: Glucocorticoids suppress transcriptional up-regulation of bradykinin receptors in a murine in vitro model of chronic airway inflammation. Clin Exp Allergy 2005, 35(4):531-538.

23. Bachar O, Adner M, Uddman R, Cardell LO: Toll-like receptor stimulation induces airway hyper-responsiveness to bradykinin, an effect mediated by JNK and NF-kappa B signaling pathways. Eur J Immunol 2004, 34(4):1196-1207.

24. Gotti C, Balestra B, Moretti M, Rovati GE, Maggi L, Rossoni G, Berti F, Villa L, Pallavicini M, Clementi F: 4-Oxystilbene compounds are selective ligands for neuronal nicotinic alphaBungarotoxin receptors. Br J Pharmacol 1998, 124(6):1197-1206.

25. Lawson CJ, Homewood J, Taylor AJ: The Effects of L-glucose on memory in mice are modulated by peripherally acting cholinergic drugs. Neurobiol Learn Mem 2002, 77(1):17-28.
26. Aoki M, Kobayashi M, Ishikawa J, Saita Y, Terai Y, Takayama K, Miyata K, Yamada T: A novel phosphodiesterase type 4 inhibitor, YM976 (4-(3chlorophenyl)-1, 7-diethylpyrido[2,3-d]pyrimidin-2(1H)-one), with little emetogenic activity. J Pharmacol Exp Ther 2000, 295(1):255-260.

27. Conti-Fine BM, Navaneetham D, Lei S, Maus AD: Neuronal nicotinic receptors in non-neuronal cells, new mediators of tobacco toxicity? Eur J Pharmacol 2000, 393(1-3):279-294.

28. Lindell G, Farnebo LO, Chen D, Nexo E, Rask Madsen J, Bukhave K, Graffner $\mathrm{H}$ : Acute effects of smoking during modified sham feeding in duodenal ulcer patients. An analysis of nicotine, acid secretion, gastrin, catecholamines, epidermal growth factor, prostaglandin E2, and bile acids. Scand J Gastroenterol 1993, 28(6):487-494.

29. Clunes $L A$, Bridges A, Alexis N, Tarran R: In vivo versus in vitro airway surface liquid nicotine levels following cigarette smoke exposure. J Anal Toxicol 2008, 32(3):201-207.

30. Carlisle DL, Liu X, Hopkins TM, Swick MC, Dhir R, Siegfried JM: Nicotine activates cell-signaling pathways through muscle-type and neuronal nicotinic acetylcholine receptors in non-small cell lung cancer cells. Pulm Pharmacol Ther 2007, 20(6):629-641.

31. Koshi R, Sugano N, Orii H, Fukuda T, Ito K: Microarray analysis of nicotineinduced changes in gene expression in a macrophage-like human cell line. J Periodontal Res 2007, 42(6):518-526.

32. Berman AR, Togias AG, Skloot G, Proud D: Allergen-induced hyperresponsiveness to bradykinin is more pronounced than that to methacholine. J Appl Physiol 1995, 78(5):1844-1852.

33. Eric J, Gabra BH, Sirois P: Implication of the bradykinin receptors in antigen-induced pulmonary inflammation in mice. Br J Pharmacol 2003, 138(8):1589-1597.

34. Huang TJ, Haddad EB, Fox AJ, Salmon M, Jones C, Burgess G, Chung KF: Contribution of bradykinin $B(1)$ and $B(2)$ receptors in allergen-induced bronchial hyperresponsiveness. Am J Respir Crit Care Med 1999, 160(5 Pt 1):1717-1723.

35. Kusser B, Braun A, Praun M, Illi S, von Mutius E, Roscher AA: Polymorphisms in the bradykinin B2 receptor gene and childhood asthma. Biol Chem 2001, 382(5):885-889.

36. Roomans G, Vanthanouvong V, Dragomir A, Kozlova I, Wróblewski R: Effects of nicotine on intestinal and respiratory epithelium. J Submicrosc Cytol Pathol 2002, 34(4):381-388.

37. Birrell MA, Wong S, Catley MC, Belvisi MG: Impact of tobacco-smoke on key signaling pathways in the innate immune response in lung macrophages. J Cell Physiol 2008, 214(1):27-37.

38. Adcock IM, Chung KF, Caramori G, Ito K: Kinase inhibitors and airway inflammation. Eur J Pharmacol 2006, 533(1-3):118-132.

39. Xu CB, Zheng JP, Zhang W, Zhang Y, Edvinsson L: Lipid-soluble smoke particles upregulate vascular smooth muscle ETB receptors via activation of mitogen-activating protein kinases and NF-kappaB pathways. Toxicol Sci 2008, 106(2):546-555.

40. De Bie JJ, Hessel EM, Van Ark I, Van Esch B, Hofman G, Nijkamp FP, Van Oosterhout AJ: Effect of dexamethasone and endogenous corticosterone on airway hyperresponsiveness and eosinophilia in the mouse. $\mathrm{Br} J$ Pharmacol 1996, 119(7):1484-1490.

41. Trifilieff A, El-Hashim A, Bertrand C: Time course of inflammatory and remodeling events in a murine model of asthma, effect of steroid treatment. Am J Physiol Lung Cell Mol Physiol 2000, 279(6):L1120-1128.

42. Haddad EB, Fox AJ, Rousell J, Burgess G, Mclntyre P, Barnes PJ, Chung KF: Post-transcriptional regulation of bradykinin $\mathrm{B} 1$ and $\mathrm{B} 2$ receptor gene expression in human lung fibroblasts by tumor necrosis factor-alpha: modulation by dexamethasone. Mol Pharmacol 2000, 57(6):1123-1131.

43. Schmidlin F, Scherrer D, Landry Y, Gies JP: Glucocorticoids inhibit the bradykinin $B 2$ receptor increase induced by interleukin-1 beta in human bronchial smooth muscle cells. Eur J Pharmacol 1998, 354(1):R7-8.

44. Barnes PJ: Therapeutic strategies for allergic diseases. Nature 1999 402(6760 Suppl):B31-38.

45. Schulze-Osthoff K, Ferrari D, Riehemann K, Wesselborg S: Regulation of NF-kappa B activation by MAP kinase cascades. Immunobiology 1997, 198(1-3):35-49.

46. Barr J, Sharma CS, Sarkar S, Wise K, Dong L, Periyakaruppan A, Ramesh GT: Nicotine induces oxidative stress and activates nuclear transcription factor kappa B in rat mesencephalic cells. Mol Cell Biochem 2007, 297(1-2):93-99. 
47. Gensch E, Gallup M, Sucher A, Li D, Gebremichael A, Lemjabbar H, Mengistab A, Dasari V, Hotchkiss J, Harkema J, et al: Tobacco smoke control of mucin production in lung cells requires oxygen radicals AP-1 and JNK. J Biol Chem 2004, 279(37):39085-39093.

48. Zhou Y, Ling EA, Dheen ST: Dexamethasone suppresses monocyte chemoattractant protein-1 production via mitogen activated protein kinase phosphatase-1 dependent inhibition of Jun N-terminal kinase and p38 mitogen-activated protein kinase in activated rat microglia. J Neurochem 2007, 102(3):667-678.

49. Bergmann MW, Staples KJ, Smith SJ, Barnes PJ, Newton R: Glucocorticoid inhibition of granulocyte macrophage-colony-stimulating factor from $T$ cells is independent of control by nuclear factor-kappaB and conserved lymphokine element 0. Am J Respir Cell Mol Biol 2004, 30(4):555-563.

50. Torphy TJ, Undem BJ, Cieslinski LB, Luttmann MA, Reeves ML, Hay DW: Identification, characterization and functional role of phosphodiesterase isozymes in human airway smooth muscle. J Pharmacol Exp Ther 1993 265(3):1213-1223.

51. Toward TJ, Broadley KJ: Chronic lipopolysaccharide exposure on airway function, cell infiltration, and nitric oxide generation in conscious guinea pigs: effect of rolipram and dexamethasone. J Pharmacol Exp Ther 2001, 298(1):298-306.

52. Sanz MJ, Cortijo J, Morcillo EJ: PDE4 inhibitors as new anti-inflammatory drugs: effects on cell trafficking and cell adhesion molecules expression. Pharmacol Ther 2005, 106(3):269-297.

53. Ammit AJ, Hoffman RK, Amrani Y, Lazaar AL, Hay DW, Torphy TJ, Penn RB, Panettieri RA Jr: Tumor necrosis factor-alpha-induced secretion of RANTES and interleukin-6 from human airway smooth-muscle cells. Modulation by cyclic adenosine monophosphate. Am J Respir Cell Mol Biol 2000, 23(6):794-802.

54. Kaur M, Holden NS, Wilson SM, Sukkar MB, Chung KF, Barnes PJ, Newton R, Giembycz MA: Effect of beta2-adrenoceptor agonists and other CAMPelevating agents on inflammatory gene expression in human ASM cells: a role for protein kinase A. Am J Physiol Lung Cell Mol Physiol 2008, 295(3): L505-514.

55. Li X, Zarinetchi F, Schrier RW, Nemenoff RA: Inhibition of MAP kinase by prostaglandin E2 and forskolin in rat renal mesangial cells. Am J Physiol 1995, 269(4 Pt 1):C986-991.

doi:10.1186/1465-9921-11-13

Cite this article as: Xu et al: Nicotine enhances murine airway

contractile responses to kinin receptor agonists via activation of JNK-

and PDE4-related intracellular pathways. Respiratory Research 2010 11:13.

\section{Submit your next manuscript to BioMed Central and take full advantage of:}

- Convenient online submission

- Thorough peer review

- No space constraints or color figure charges

- Immediate publication on acceptance

- Inclusion in PubMed, CAS, Scopus and Google Scholar

- Research which is freely available for redistribution 